\title{
Does Hypoxia Decrease the Metabolic Rate?
}

\author{
Chenjuan Gu and Jonathan C. Jun* \\ Division of Pulmonary and Critical Care, Department of Medicine, Johns Hopkins University, Baltimore, MD, United States
}

In some organisms and cells, oxygen availability influences oxygen consumption. In this review, we examine this phenomenon of hypoxic hypometabolism $(\mathrm{HH})$, discussing its features, mechanisms, and implications. Small mammals and other vertebrate species exhibit "oxyconformism," a downregulation of metabolic rate and body temperature during hypoxia which is sensed by the central nervous system. Smaller body mass and cooler ambient temperature contribute to a high metabolic rate in mammals. It is this hypermetabolic state that is suppressed by hypoxia leading to $\mathrm{HH}$. Larger mammals including humans do not exhibit $\mathrm{HH}$. Tissues and cells also exhibit reductions in respiration during hypoxia in vitro, even at oxygen levels ample for mitochondrial oxidative phosphorylation. The mechanisms of cellular $\mathrm{HH}$ involve intracellular oxygen sensors including hypoxia-inducible factors, AMP-activated protein kinase (AMPK), and mitochondrial reactive oxygen species (ROS) which downregulate mitochondrial activity and ATP utilization. $\mathrm{HH}$ has a profound impact on cardiovascular, respiratory,

OPEN ACCESS

Edited by:

Jan Polák,

Charles University, Czechia

Reviewed by:

Margaret Ashcroft,

University of Cambridge,

United Kingdom

Lorna Grindlay Moore,

University of Colorado, United States

*Correspondence:

Jonathan C. Jun jjun2@jhmi.edu

Specialty section:

This article was submitted to

Diabetes,

a section of the journal

Frontiers in Endocrinology

Received: 16 August 2018

Accepted: 26 October 2018

Published: 13 November 2018

Citation:

Gu C and Jun JC (2018) Does Hypoxia Decrease the Metabolic Rate? Front. Endocrinol. 9:668. doi: 10.3389/fendo.2018.00668 and metabolic physiology in rodents. Therefore, caution should be exercised when extrapolating the results of rodent hypoxia studies to human physiology.

Keywords: hypoxia, metabolism, oxygen, metabolic rate, temperature

\section{BACKGROUND}

Hypoxia is defined as reduced oxygen $\left(\mathrm{O}_{2}\right)$ in the environment or in an organism (1). Arterial hypoxia is detected by $\mathrm{O}_{2}$ sensitive cells primarily located in the carotid body. Activation of the carotid bodies stimulates hyperventilation and activates the sympathetic nervous system. Peripheral tissues also mount local responses to hypoxia. For example, skeletal muscle vasculature dilates to permit greater blood flow (2). Reduced oxygen in the kidney and liver tissues upregulates the expression of erythropoietin, leading to increased hemoglobin. Angiogenesis is stimulated by growth factors such as vascular endothelial growth factor 1 . Thus, hypoxia activates several systems that increase $\mathrm{O}_{2}$ delivery.

Another defense against hypoxia is a downregulation of metabolic rate $/ \mathrm{O}_{2}$ demand. Throughout the animal kingdom, both vertebrates and invertebrates can dramatically reduce metabolic rate and body temperature $\left(\mathrm{T}_{b}\right)$ in response to cold or reduced $\mathrm{O}_{2}$ levels. Hypoxia reduces $\mathrm{T}_{\mathrm{b}}$ in both endothermic (e.g., mammals) and ectothermic (e.g., reptiles) vertebrates (3). In hibernating mammals, metabolism can reversibly fall to $2 \%$ of basal metabolic rate (BMR) $(4,5)$. The drop in metabolic rate during hypoxia was defined as "Hypoxic hypometabolism" by Mortola et al. in the early 1990s (6). This hypometabolic state conserves oxygen stores (7) and protects against ischemic injury after cardiac arrest (8). Freshwater turtles can survive for months with minimal $\mathrm{O}_{2}$ during winter hibernation (9). In this review, we will examine features, mechanisms, and implications of hypoxic hypometabolism $(\mathrm{HH})$ and hypoxia-induced hypothermia. 


\section{HYPOXIC HYPOMETABOLISM}

"Oxyregulators" are organisms that maintain metabolic rate regardless of $\mathrm{O}_{2}$ availability, while "oxyconformers" decrease energy expenditure in the face of lower $\mathrm{O}_{2}$ availability (6). Most mammals including humans are oxyregulators: as $\mathrm{O}_{2}$ supply decreases (e.g., ischemia, exercise) anaerobic pathways supply ATP to compensate for the $\mathrm{O}_{2}$ debt. Other vertebrates, exemplified by the crucian carp, and common frog primarily use $\mathrm{HH}$ to reduce ATP demand (10). Small mammals (newborn humans, kittens, rats, adult guinea pigs) are oxyconformers, lowering their oxygen consumption $\left(\dot{\mathrm{V}}_{2}\right)$, and $\mathrm{T}_{\mathrm{b}}$, even in relatively mild hypoxia (11). Studies in the 1950's identified two factors that influenced the magnitude of $\mathrm{HH}$ in mammals: ambient temperature and body mass (12). Hypoxia inhibits shivering and non-shivering thermogenesis, which are costly energetic processes. The thermoneutral zone (TNZ) is the range of ambient temperatures where BMR is determined, since thermogenic energy expenditure is at a minimum (13). Seminal studies by Hill (14) elegantly showed that $\dot{\mathrm{VO}}_{2}$ and $\mathrm{T}_{\mathrm{b}}$ decreased in newborn kittens exposed to hypoxia $\left(10 \% \mathrm{O}_{2}\right)$ at an ambient temperature of $28^{\circ} \mathrm{C}$ (below TNZ), but not in the TNZ $\left(34^{\circ} \mathrm{C}\right)$. The effect has now been termed regulated hypothermia, or hypoxia-induced anapyrexia (15), and involves selection of a cooler environment (16), increased dissipation of heat (17), suppression of shivering $(18,19)$, and inactivation of brown fat thermogenesis (20).

The relatively large surface area to body mass of small mammals causes substantial heat dissipation, requiring a high BMR that rises rapidly for each degree below $\operatorname{TNZ}(21,22)$. Frappell et al. compared several newborn mammals and found that mammals weighing $>2 \mathrm{~kg}$ exhibited minimal $\mathrm{HH}$ or hypoxic hypothermia (23). Larger mammals have a lower weight-adjusted $\mathrm{BMR}$, reduced thermosensitivity, a lower TNZ, and a blunted rise of $\mathrm{VO}_{2}$ per degree below TNZ (24). The TNZ of a human lies in $18-22^{\circ} \mathrm{C}$ (clothed) or $25-30^{\circ} \mathrm{C}$ (unclothed) range. The $\mathrm{TNZ}$ of mice is $\sim 30-34^{\circ} \mathrm{C}$. Thus, "room temperature" $\left(22^{\circ} \mathrm{C}\right)$ approximates the TNZ for clothed humans but is far below TNZ for mice; the metabolic rate of a mice housed at $22^{\circ} \mathrm{C}$ will be $50 \%$ above its BMR (13).

\section{MECHANISMS OF HYPOXIC HYPOMETABOLISM}

Features of $\mathrm{HH}$ and hypoxia-induced hypothermia have been characterized in detail, but underlying mechanisms are not fully understood. It is clear that $\mathrm{HH}$ is not caused by anaerobic metabolism or "oxygen debt" (23), which suggests that $\mathrm{HH}$ is a regulated process. Tamaki and Nakayama showed that preoptic hypothalamic neurons became less temperature sensitive in anesthetized rats when exposed to $10 \% \mathrm{O}_{2}$ (25). Tattersall and Milsom showed that the threshold for hypothalamic activation to central cooling decreased from $38^{\circ} \mathrm{C}$ in normoxia to $28 \sim 31^{\circ} \mathrm{C}$ at $7 \% \mathrm{O}_{2}$ by delivering a cold stimulus to the brains of ground squirrels using implanted thermodes (12). Less certain is how hypoxia is sensed by the hypothalamus leading to $\mathrm{HH}$.
Matsuoka et al. (26) reported that anemic hypoxia (normal $\mathrm{PaO}_{2}$ ) reduced $\mathrm{VO}_{2}$ in rats, indicating that $\mathrm{HH}$ does not require activation of the carotid body. This provides circumstantial evidence that $\mathrm{O}_{2}$-sensitive neural networks in the brainstem, already known to regulate respiratory and sympathetic activity (27) may relay information to the preoptic hypothalamus. How $\mathrm{O}_{2}$ is sensed within cells involves several regulatory proteins, ion channels, and mitochondrial reactive oxygen species (ROS) (28). Adenosine may increase during hypoxia and signal thermoregulatory changes at the preoptic hypothalamus. Barros et al. found that an adenosine A1 receptor antagonist attenuated $\mathrm{HH}$ in rats $(29,30)$. Hypoxia-induced anapyrexia may also involve neurotransmitters such as hydrogen sulfide (31), endogenous opioids (32), and nitric oxide (33). Effectors of heat generation may also be affected by local $\mathrm{O}_{2}$ tension. Hypoxia causes the stabilization of hypoxia-inducible factor-1 (HIF-1), which controls the transcription of many genes. HIF-1 may suppress $\mathrm{O}_{2}$ consumption and heat production from brown adipose tissue (20). It is estimated that resting $\mathrm{VO}_{2}$ decreases by $11 \%$ per degree fall in $\mathrm{T}_{\mathrm{b}}$ due to slower enzymatic reaction rates (the " $\mathrm{Q}_{10}$ " effect) (3). However, the fact that $\mathrm{V}_{2}$ decreases before $\mathrm{T}_{\mathrm{b}}$, and falls to a greater extent than predicted by $\mathrm{Q}_{10}$ effects, argues against hypothermia per se causing $\mathrm{HH}$. Regardless of the pathways involved, $\mathrm{HH}$ and lower $\mathrm{T}_{\mathrm{b}}$ act synergistically to increase survival (11). In summary, animals that exhibit $\mathrm{HH}$ conform their metabolic demands to reduced $\mathrm{O}_{2}$ availability sensed in brain.

\section{HYPOXIC HYPOMETABOLISM AT THE CELL LEVEL}

The above discussion focused on the decrease in whole body $\mathrm{VO}_{2}$ and $\mathrm{T}_{\mathrm{b}}$ in response to hypoxia. Oxygen conformism also occurs at the cellular level (10). Below a critical anoxic threshold, cell death occurs if $\mathrm{O}_{2}$ availability fails to meet ATP demands of $\mathrm{Na}-\mathrm{K}$-ATPases and voltage-gated $\mathrm{Ca}^{2+}$ channels. Cells from different species and organs exhibit varying levels of anoxia tolerance. Organisms that exhibit significant hypoxia tolerance are comprised of cells capable of suppressing activity of ionmotive ATPases, a protein pump which allows ions to move against the electrochemical potential gradient across biological membranes at the expense of ATP hydrolysis. This phenomenon is termed "channel arrest" (34). Turtle and frog tissues (liver, heart, brain) can reversibly reduce respiratory rates by $75 \%$ within $30 \mathrm{~min}$ of exposure to anoxia (10). Similarly, hypoxia can induce complete and reversible arrest of mitochondrial respiration and ATP synthesis in liver cells of diving seals (35). Mechanisms of channel arrest in anoxia tolerant cells is not known, but may involve adenosine accumulation as a signaling molecule. By contrast, cells from oxyregulators do not exhibit decreases in ATP demand for maintaining ion gradients (10).

Cellular respiration decreases even at moderately reduced $\mathrm{O}_{2}$ levels (1-3\%), well above the threshold $\left(<0.3 \% \mathrm{O}_{2}\right)$ for arresting $\mathrm{O}_{2}$-dependent ATP generation at mitochondrial complex IV (36). For example, isolated rat hepatocytes exhibited a reversible fall in $\mathrm{VO}_{2}$ after several hours of exposure to $\sim 10 \% \mathrm{O}_{2}$ (37); chick 
cardiac myocytes also exhibited $\mathrm{HH}$ and decreased contractility with evidence of reduced mitochondrial complex IV activity (38). Under normoxic conditions, cellular $\mathrm{VO}_{2}$ in cells is determined by factors including rates of ATP synthesis, transport and utilization (50\%), NADH supply generated from pyruvate flux and the tricarboxylic acid (TCA) cycle (15-30\%), proton leak (0-15\%), and the electron transport chain (ETC) (39). These processes are not affected by brief hypoxia, but within a few hours, carbon flux through the TCA, and electron flux through the ETC both decrease (36). Cellular $\mathrm{HH}$ is mediated in part through stabilization of HIF- $1 \alpha$. HIF-1 shifts metabolism toward glycolysis via upregulating numerous glycolytic genes $(40,41)$, a phenomenon called the Pasteur effect (42). HIF-1 actively suppresses the TCA cycle by trans-activating the gene encoding pyruvate dehydrogenase kinase 1 (PDK1), which inactivates pyruvate dehydrogenase $(\mathrm{PDH})$. $\mathrm{PDH}$ is responsible for the conversion of pyruvate to acetyl-CoA. The net result is a shunting of pyruvate away from the TCA cycle and toward glycolysis, as well as a fall in mitochondrial $\mathrm{VO}_{2}$ and an increase in intracellular $\mathrm{O}_{2}$ tension $(43,44)$.

Reduced electron flux through the ETC during sustained hypoxia occurs via several mechanisms, some of which are dependent upon HIF-1. First, HIF-1 targets inducible nitric oxide synthase (iNOS), and nitric oxide in turn suppresses mitochondrial complex IV activity. Second, HIF-1 stimulates micro-RNA 210, which inhibits the function of several mitochondrial membrane complexes. Third, HIF-1 induces a switch of subunits expressed in complex IV, which increases its efficiency (45). Another major mechanism of $\mathrm{HH}$ involves inhibition of ATP utilization. Hypoxia inhibits plasma membrane Na-K-ATPase activity, which may account for up to $70 \%$ of mammalian cellular $\dot{\mathrm{VO}}_{2}(46)$. Hypoxia $\left(1.5 \% \mathrm{O}_{2}\right)$ was shown to cause ubiquitin degradation of the Na-K-ATPase alpha subunit (47). In addition, hypoxia inhibits cellular mRNA translation. The reduction of Na-K-ATPase activity and protein translation are both mediated by an $\mathrm{O}_{2}$ sensor, AMP-activated protein kinase (AMPK) which is activated by mitochondrial ROS (36). Mechanisms of $\mathrm{HH}$ at the cellular level are complex and remain under active investigation.

\section{DO HUMANS EXPERIENCE HYPOXIC HYPOMETABOLISM?}

Humans (other than newborns) would be classified as oxyregulators, and do not exhibit $\mathrm{HH}$. In fact, the cardiovascular stress of hypoxia is often accompanied by changes such as hyperventilation that increase $\mathrm{O}_{2}$ delivery and increase $\mathrm{V}_{2}$. Exposure to high altitude (hypobaric hypoxia) is accompanied by weight loss, with increased energy expenditure being one of the mechanisms (48). For example, the metabolic rate of male sea level natives increased $27 \%$ on day 2 after ascent to $4,300 \mathrm{~m}$, and remained $17 \%$ higher than baseline on day 10 (49). High altitude exposure also increases rates of glucose turnover in the body, at rest and during exercise (50). BMR of workers residing in the Andes $(\sim 4,500 \mathrm{~m})$ for $>4$ months showed values comparable to standard BMR measurements at sea level, and higher than sea level values when normalized to lean body mass (51). This finding is in line with older studies of acute high altitude exposure showing a rise in $\mathrm{VO}_{2}$ (52). Interestingly, six scientific expeditioners to the Himalayas $(5,800 \mathrm{~m})$ showed a $10 \%$ increase, while their 3 Sherpa guides (chronic dwellers at $1,800 \mathrm{~m}$ ) exhibited a $21 \%$ increase in $\mathrm{V}_{2}$ compared to sea level standards (53). Normobaric hypoxia (breathing $10 \% \mathrm{O}_{2}$ for $40 \mathrm{~min}$ ) resulted in a $15.5 \%$ increase in cerebral blood flow and $8.5 \%$ increase in cerebral metabolic rate in healthy subjects, as measured by magnetic resonance imaging (54).

Hypoxia lowers peak $\dot{\mathrm{VO}}_{2}$ and causes an earlier shift to anaerobic metabolism during intensive exercise (55-57). However, this lowering of $\dot{\mathrm{VO}}_{2 \text { max }}$ should not be equated with $\mathrm{HH}$. $\dot{\mathrm{V}} \mathrm{O}_{2}$ continues to rise at work rates above anaerobic threshold. Thus, humans and larger mammals cope with hypoxia by "defending" ATP production rather than conforming to a lower $\mathrm{VO}_{2}$. It is possible that long-term hypoxic adaptation can induce changes in metabolism of certain tissues. For example, Hochachka et al. (58) examined brain regional glucose metabolic rates in Quechua natives indigenous to the Andes (3,700$4,900 \mathrm{~m}$ ), with positron emission tomographic imaging. These high-altitude dwellers demonstrated lower glucose metabolic rates than that of lowlanders. However, there is no evidence that acute or chronic hypoxia reduces overall $\mathrm{VO}_{2}$ in humans.

\section{DO HUMANS EXPERIENCE HYPOXIA-INDUCED ANAPYREXIA?}

It is unclear whether hypoxia significantly alters thermoregulation in humans. DiPasquale et al. studied subjects breathing 21,14 , or $12 \% \mathrm{O}_{2}$ for $30 \mathrm{~min}$ at thermoneutrality. They showed that hypoxia modestly decreased rectal temperature, with each $1 \%$ decrease in $\mathrm{SpO}_{2}$ decreasing the temperature by $0.15^{\circ} \mathrm{C}(59)$. However, Seo et al. questioned possible carryover effects of the brief interventions of this study which were performed in a single session per subject. Their group studied thermal responses to similar degrees of normobaric hypoxia, distributing exposures across days, and did not find a reduction in rectal temperature, metabolic heart production, or heat loss (60). Other studies used cold exposure to elicit changes in thermoregulation with hypoxia. Eight subjects immersed in $28^{\circ} \mathrm{C}$ water were exposed to eucapnic hypoxia $\left(12 \% \mathrm{O}_{2}\right)$ which lowered core temperature threshold for vasoconstriction and shivering by 0.14 and $0.19^{\circ} \mathrm{C}$, respectively, while increasing core cooling rate (61). Robinson and Haymes exposed subjects to normoxia or hypoxia $\left(12 \% \mathrm{O}_{2}\right)$, at an ambient temperature of 25 or $8^{\circ} \mathrm{C}$. Under cold conditions, hypoxia modestly lowered $\dot{\mathrm{VO}}_{2}$ and rectal temperature. During cold exercise, hypoxia accelerated heat loss (62). Another study examined the acute effects of normobaric hypoxia on hand temperature responses during and after a 30-min local cold-water immersion test. Although hypoxia did not aggravate the cold-induced drop in hand temperature, hypoxia impaired rewarming (63).

Some studies examined thermoregulation at high altitude, an environment that often combines hypobaric hypoxia with cold temperature. Savourey et al. (64) studied 11 lowlander subjects 
after 2 weeks of high altitude residence in the Andes (4,150 $\sim 6,885 \mathrm{~m})$. Metabolic heat production in response to a cold air test $\left(2 \mathrm{~h}\right.$ of $1^{\circ} \mathrm{C}$ exposure) was modestly diminished and heat debt increased, whereas upper-extremity skin temperature was reduced by $\sim 1.45^{\circ} \mathrm{C}$ in a local coldwater test $(5 \mathrm{~min}$ of $5^{\circ} \mathrm{C}$ exposure) after 2 weeks at high altitude. In study that controlled for ambient temperature, five men were exposed to acute intermittent hypoxia $(\mathrm{AIH})$ in a chamber $(8 \mathrm{~h}$ daily for $4 \mathrm{~d}, 6 \mathrm{~h}$ on the last day, $4,500-6,000 \mathrm{~m})$ at $24^{\circ} \mathrm{C}$. Under these conditions, cold challenge testing demonstrated that $\mathrm{AIH}$ caused lower skin temperature, without significant change in rectal temperature. Interestingly, metabolic heat production increased by $7 \%$ and heat debt and convective heat loss decreased. Time to onset for continuous shivering also decreased (65). O'Brien et al. (66) performed finger cold water immersion tests in healthy males in a thermoneutral hypobaric chamber at simulated sea level, 3,000 and 4,675 m. No effect of hypobaric hypoxia on the finger temperature response was observed. In summary, hypoxia may impair thermoregulation in adult humans, but effects are small and may require superimposed cold exposure to become evident.

\section{IMPLICATIONS OF HYPOXIC HYPOMETABOLISM}

\section{Animal Physiology}

$\mathrm{HH}$ influences cardiovascular and respiratory physiology of small mammals. Mice housed at typical lab temperature $\left(22^{\circ} \mathrm{C}\right)$ exhibit high sympathetic activity, low cardiac vagal tone, and a higher resting heart rate compared to mice housed at TNZ (67). In a rodent study using three different species (rats, ground squirrel, and hamster), hypoxia resulted in cardiac acceleration in all species in a warm environment $\left(35^{\circ} \mathrm{C}\right)$, while decreasing heart rate at an ambient temperature of $10^{\circ} \mathrm{C}$ (68). Similarly, the magnitude of the hypoxic ventilatory response (HVR) is modified by $\mathrm{HH}$ (69). When rats of different sizes were exposed to $10 \%$ $\mathrm{O}_{2}$ at an ambient temperature of $\sim 24^{\circ} \mathrm{C}, 400 \mathrm{~g}$ rats had much stronger HVR than $50 \mathrm{~g}$ rats associated with a minimal degree of $\mathrm{HH}$ in the larger animals (70). More directly it was shown that inhaled hydrogen sulfide induced $\mathrm{HH}$ in mice, and mediated a reduction in HVR (71). Substrate metabolism under hypoxic conditions is also highly influenced by ambient temperature. To see if acute hypoxia increases plasma triglycerides (TG), we exposed postprandial mice housed at $22^{\circ} \mathrm{C}$ to $6 \mathrm{~h}$ of graded hypoxia. Hypoxia dose-dependently increased TG [as seen in a previous rat studies $(72,73)]$ contained within large, low-density lipoproteins while decreasing TG clearance, and decreasing fatty acid uptake in brown adipose tissue (74). When mice were exposed to $10 \% \mathrm{O}_{2}$ at thermoneutrality $\left(30^{\circ} \mathrm{C}\right)$ hypoxia had no effect on TG levels, clearance rate, or brown adipose tissue

\section{REFERENCES}

1. Connett RJ, Honig CR, Gayeski TE, Brooks GA. Defining hypoxia: a systems view of VO2, glycolysis, energetics, and intracellular PO2. J Appl Physiol. (1990) 68:833-42. doi: 10.1152/jappl.1990.68.3.833 lipid uptake. Moreover, thermoneutral hypoxia increased cardiac lipid uptake and plasma HDL cholesterol (75). Baum et al. found that hypoxia inhibited lipolysis in puppies exposed to cold (76). However, hypoxia stimulated lipolysis in mice under thermoneutral conditions $(75,77)$ with more variable responses below TNZ (74).

\section{Translational Research}

Small mammal studies performed below TNZ would indicate that hypoxia lowers $\mathrm{VO}_{2}$ (14), reduces heart rate (68), minimally increases ventilation (70), causes an atherogenic lipid profile $(72$, 73), and inhibits lipolysis (76). However, many of these changes are manifestations of cold-elicited $\mathrm{HH}$. Hypoxia in rodents at TNZ better approximates the human response, characterized by a preserved $\dot{\mathrm{VO}}_{2}$, robust $\mathrm{HVR}$ and heart rate acceleration, no change (78) or reduced TG (75), increased HDL cholesterol (79), and a stimulation of adipose tissue lipolysis (78, 80, 81). Therefore, ambient temperature is a critical variable in translational hypoxia studies. To "humanize" small mammal hypoxia research, $\mathrm{HH}$ can be minimized by housing animals at TNZ.

\section{Clinical Research}

Understanding $\mathrm{HH}$ may have clinical applications. Downregulation of metabolism is evident in myocardium during ischemia (82). Pre-conditioning tissues to hypoxia may mitigate ischemia-reperfusion injury (83). Cancer cells invoke $\mathrm{HH}$ to promote survival in hypoxic tumors $(84,85)$. HH may be an adaptive strategy for neonatal humans at risk for sudden infant death (86). Therefore, pathways of $\mathrm{HH}$ may be leveraged for human disease.

\section{CONCLUSIONS}

In oxygen "conformers" hypoxia can reduce metabolic rate, at the whole body and cellular level. Factors that determine the extent of $\mathrm{HH}$ include the degree of hypoxia, ambient temperature, body mass, and species or cell type. Knowledge of these factors is critical for the design and interpretation of hypoxia studies. The ability to manipulate $\mathrm{HH}$ may also have significant therapeutic implications.

\section{AUTHOR CONTRIBUTIONS}

CG and JJ wrote the manuscript and had final approval of the submitted version.

\section{FUNDING}

Grant support: R01HL135483, R03HL138068, P30DK072488.
2. Dinenno FA. Skeletal muscle vasodilation during systemic hypoxia in humans. J Appl Physiol. (2016) 120:216-25. doi: 10.1152/japplphysiol. 00256.2015

3. Wood SC. Interactions between hypoxia and hypothermia. Annu Rev Physiol. (1991) 53:71-85. doi: 10.1146/annurev.ph.53.030191.000443 
4. Geiser F. Metabolic rate and body temperature reduction during hibernation and daily torpor. Annu Rev Physiol. (2004) 66:239-74. doi: 10.1146/annurev.physiol.66.032102.115105

5. Larson J, Drew KL, Folkow LP, Milton SL, Park TJ. No oxygen? No problem! Intrinsic brain tolerance to hypoxia in vertebrates. J Exp Biol. (2014) 217:1024-39. doi: 10.1242/jeb.085381

6. Mortola JP. Hypoxic hypometabolism in mammals. Physiology (1993) 8:7982. doi: 10.1152/physiologyonline.1993.8.2.79

7. Ma YL, Zhu X, Rivera PM, Toien O, Barnes BM, LaManna JC, et al. Absence of cellular stress in brain after hypoxia induced by arousal from hibernation in Arctic ground squirrels. Am J Physiol Regul Integr Comp Physiol. (2005) 289:R1297-306. doi: 10.1152/ajpregu.00260.2005

8. Dave KR, Prado R, Raval AP, Drew KL, Perez-Pinzon MA. The arctic ground squirrel brain is resistant to injury from cardiac arrest during euthermia. Stroke (2006) 37:1261-5. doi: 10.1161/01.STR.0000217409. 60731.38

9. Storey KB. Anoxia tolerance in turtles: metabolic regulation and gene expression. Comp Biochem Physiol Part A Mol Integr Physiol. (2007) 147:26376. doi: 10.1016/j.cbpa.2006.03.019

10. Boutilier RG. Mechanisms of cell survival in hypoxia and hypothermia. $J$ Exp Biol. (2001) 204:3171-81. Available online at: http://jeb.biologists.org/ content/204/18/3171.short

11. Mortola JP. Implications of hypoxic hypometabolism during mammalian ontogenesis. Respir Physiol Neurobiol. (2004) 141:345-56. doi: 10.1016/j.resp.2004.01.011

12. Tattersall GJ, Milsom WK. Hypoxia reduces the hypothalamic thermogenic threshold and thermosensitivity. J Physiol. (2009) 587:5259-74. doi: 10.1113/jphysiol.2009.175828

13. Maloney SK, Fuller A, Mitchell D, Gordon C, Overton JM. Translating animal model research: does it matter that our rodents are cold? Physiology (2014) 29:413-20. doi: 10.1152/physiol.00029.2014

14. Hill JR. The oxygen consumption of new-born and adult mammals. Its dependence on the oxygen tension in the inspired air and on the environmental temperature. J Physiol. (1959) 149:346-73. doi: 10.1113/jphysiol.1959.sp006344

15. Steiner AA, Branco LG. Hypoxia-induced anapyrexia: implications and putative mediators. Annu Rev Physiol. (2002) 64:263-88. doi: 10.1146/annurev.physiol.64.081501.155856

16. Gordon CJ, Fogelson L. Comparative effects of hypoxia on behavioral thermoregulation in rats, hamsters, and mice. Am J Physiol. (1991) 260:R1205. doi: 10.1152/ajpregu.1991.260.1.R120

17. Tattersall GJ, Milsom WK. Transient peripheral warming accompanies the hypoxic metabolic response in the golden-mantled ground squirrel. J Exp Biol. (2003) 206:33-42. doi: 10.1242/jeb.00057

18. Barros RC, Zimmer ME, Branco LG, Milsom WK. Hypoxic metabolic response of the golden-mantled ground squirrel. J Appl Physiol. (2001) 91:603-12. doi: 10.1152/jappl.2001.91.2.603

19. Gautier H, Bonora M, Schultz SA, Remmers JE. Hypoxia-induced changes in shivering and body temperature. J Appl Physiol. (1987) 62:2477-84. doi: 10.1152/jappl.1987.62.6.2477

20. Jun JC, Devera R, Unnikrishnan D, Shin MK, Bevans-Fonti S, Yao Q, et al. Adipose HIF-1alpha causes obesity by suppressing brown adipose tissue thermogenesis. J Mol Med (2017) 95:287-97. doi: 10.1007/s00109-0161480-6

21. Ballesteros FJ, Martinez VJ, Luque B, Lacasa L, Valor E. On the thermodynamic origin of metabolic scaling. Sci Rep. (2018) 8:1448. doi: 10.1038/s41598-018-19853-6

22. White CR, Seymour RS. Mammalian basal metabolic rate is proportional to body mass2/3. Proc Natl Acad Sci USA. (2003) 100:4046-9. doi: 10.1073/pnas.0436428100

23. Frappell P, Lanthier C, Baudinette RV, Mortola JP. Metabolism and ventilation in acute hypoxia: a comparative analysis in small mammalian species. Am J Physiol. (1992) 262:R1040-6. doi: 10.1152/ajpregu.1992.262.6.R1040

24. Heller HC. Hypothalamic thermosensitivity in mammals. Experientia Suppl. (1978) 32:267-76. doi: 10.1007/978-3-0348-5559-4_30

25. Tamaki Y, Nakayama T. Effects of air constituents on thermosensitivities of preoptic neurons: hypoxia versus hypercapnia. Pflugers Archiv. (1987) 409:1-6. doi: 10.1007/BF00584743
26. Matsuoka T, Saiki C, Mortola JP. Metabolic and ventilatory responses to anemic hypoxia in conscious rats. J Appl Physiol. (1994) 77:1067-72. doi: 10.1152/jappl.1994.77.3.1067

27. Neubauer JA, Sunderram J. Oxygen-sensing neurons in the central nervous system.J Appl Physiol. (2004) 96:367-74. doi: 10.1152/japplphysiol. 00831.2003

28. Chandel NS, Schumacker PT. Cellular oxygen sensing by mitochondria: old questions, new insight. J Appl Physiol. (2000) 88:1880-9. doi: 10.1152/jappl.2000.88.5.1880

29. Barros RC, Branco LG, Carnio EC. Respiratory and body temperature modulation by adenosine A1 receptors in the anteroventral preoptic region during normoxia and hypoxia. Respir Physiol Neurobiol. (2006) 153:115-25. doi: 10.1016/j.resp.2005.09.013

30. Yarbrough GG, McGuffin-Clineschmidt JC. In vivo behavioral assessment of central nervous system purinergic receptors. Eur J Pharmacol. (1981) 76:137-44. doi: 10.1016/0014-2999(81)90495-7

31. Kwiatkoski M, Soriano RN, Francescato HD, Batalhao ME, Coimbra TM, Carnio EC, et al. Hydrogen sulfide as a cryogenic mediator of hypoxia-induced anapyrexia. Neuroscience (2012) 201:146-56. doi: 10.1016/j.neuroscience.2011.11.030

32. Scarpellini Cda S, Gargaglioni LH, Branco LG, Bicego KC. Role of preoptic opioid receptors in the body temperature reduction during hypoxia. Brain Res. (2009) 1286:66-74. doi: 10.1016/j.brainres.2009.06.039

33. Branco LG, Bicego KC, Carnio EC, Pittman QJ. Gaseous neurotransmitters and their role in anapyrexia. Front Biosci. (2010) 2:948-60. doi: 10.2741/e154

34. Hochachka PW. Defense strategies against hypoxia and hypothermia. Science (1986) 231:234-41. doi: 10.1126/science.2417316

35. Hochachka PW, Castellini JM, Hill RD, Schneider RC, Bengtson JL, Hill SE, et al. Protective metabolic mechanisms during liver ischemia: transferable lessons from long-diving animals. Mol Cell Biochem. (1988) 84:77-85. doi: 10.1007/BF00235195

36. Wheaton WW, Chandel NS. Hypoxia. 2. Hypoxia regulates cellular metabolism. Am J Physiol Cell Physiol. (2011) 300:C385-93. doi: 10.1152/ajpcell.00485.2010

37. Schumacker PT, Chandel N, Agusti AG. Oxygen conformance of cellular respiration in hepatocytes. Am J Physiol. (1993) 265:L395-402. doi: 10.1152/ajplung.1993.265.4.L395

38. Budinger GR, Chandel N, Shao ZH, Li CQ, Melmed A, Becker LB, et al. Cellular energy utilization and supply during hypoxia in embryonic cardiac myocytes. Am J Physiol. (1996) 270:L44-53. doi: 10.1152/ajplung.1996.270.1.L44

39. Brown GC, Lakin-Thomas PL, Brand MD. Control of respiration and oxidative phosphorylation in isolated rat liver cells. Eur J Biochem. (1990) 192:355-62. doi: 10.1111/j.1432-1033.1990.tb19234.x

40. Iyer NV, Kotch LE, Agani F, Leung SW, Laughner E, Wenger RH, et al. Cellular and developmental control of $\mathrm{O} 2$ homeostasis by hypoxia-inducible factor 1 alpha. Genes Dev. (1998) 12:149-62. doi: 10.1101/gad.12.2.149

41. Semenza GL. Hydroxylation of HIF-1: oxygen sensing at the molecular level. Physiol. (2004) 19:176-82. doi: 10.1152/physiol.00001.2004

42. Krebs HA. The Pasteur effect and the relations between respiration and fermentation. Essays Biochem. (1972) 8:1-34.

43. Kim JW, Tchernyshyov I, Semenza GL, Dang CV. HIF-1-mediated expression of pyruvate dehydrogenase kinase: a metabolic switch required for cellular adaptation to hypoxia. Cell Metab. (2006) 3:177-85. doi: 10.1016/j.cmet.2006.02.002

44. Papandreou I, Cairns RA, Fontana L, Lim AL, Denko NC. HIF-1 mediates adaptation to hypoxia by actively downregulating mitochondrial oxygen consumption. Cell Metab. (2006) 3:187-97. doi: 10.1016/j.cmet.2006. 01.012

45. Semenza GL. Oxygen-dependent regulation of mitochondrial respiration by hypoxia-inducible factor 1. Biochem J. (2007) 405:1-9. doi: 10.1042/BJ20070389

46. Milligan LP, McBride BW. Energy costs of ion pumping by animal tissues. Nutr. (1985) 115:1374-82. doi: 10.1093/jn/115.10.1374

47. Comellas AP, Dada LA, Lecuona E, Pesce LM, Chandel NS, Quesada N, et al. Hypoxia-mediated degradation of Na,K-ATPase via mitochondrial reactive oxygen species and the ubiquitin-conjugating system. Circ Res. (2006) 98:1314-22. doi: 10.1161/01.RES.0000222418.99976.1d 
48. Kayser B, Verges S. Hypoxia, energy balance and obesity: from pathophysiological mechanisms to new treatment strategies. Obes Rev. (2013) 14:579-92. doi: 10.1111/obr.12034

49. Butterfield GE, Gates J, Fleming S, Brooks GA, Sutton JR, Reeves JT. Increased energy intake minimizes weight loss in men at high altitude. (1992) J Appl Physiol. 72:1741-8. doi: 10.1152/jappl.1992.72.5.1741

50. Roberts AC, Reeves JT, Butterfield GE, Mazzeo RS, Sutton JR, Wolfel EE, et al. Altitude and beta-blockade augment glucose utilization during submaximal exercise. J Appl Physiol. (1996) 80:605-15. doi: 10.1152/jappl.1996.80. 2.605

51. Picon-Reategui E. Basal metabolic rate and body composition at high altitudes. J Appl Physiol. (1961) 16:431-4. doi: 10.1152/jappl.1961.16.3.431

52. Grover RF. Basal oxygen uptake of man at high altitude. J Appl Physiol. (1963) 18:909-12. doi: 10.1152/jappl.1963.18.5.909

53. Gill MB, Pugh LG. Basal metabolism and respiration in men living at 5,800 M (19,000 FT). J Appl Physiol. (1964) 19:949-54. doi: 10.1152/jappl.1964.19. 5.949

54. Vestergaard MB, Lindberg U, Aachmann-Andersen NJ, Lisbjerg K, Christensen SJ, Law I, et al. Acute hypoxia increases the cerebral metabolic rate - a magnetic resonance imaging study. J Cereb Blood Flow Metab. (2016) 36:1046-58. doi: 10.1177/0271678X15606460

55. Hughes RL, Clode M, Edwards RH, Goodwin TJ, Jones NL. Effect of inspired $\mathrm{O} 2$ on cardiopulmonary and metabolic responses to exercise in man. J Appl Physiol. (1968) 24:336-47. doi: 10.1152/jappl.1968.24.3.336

56. Martin D, O'Kroy J. Effects of acute hypoxia on the VO2 max of trained and untrained subjects. J Sports Sci. (1993) 11:37-42. doi: 10.1080/02640419308729961

57. Wasserman K, Koike A. Is the anaerobic threshold truly anaerobic? Chest (1992) 101:211s-8s.

58. Hochachka PW, Clark CM, Brown WD, Stanley C, Stone CK, Nickles RJ, et al. The brain at high altitude: hypometabolism as a defense against chronic hypoxia? J Cereb Blood Flow Metab. (1994) 14:671-9.

59. DiPasquale DM, Kolkhorst FW, Buono MJ. Acute normobaric hypoxia reduces body temperature in humans. High Alt Med Biol. (2015) 16:61-6. doi: 10.1089/ham.2014.1098

60. Seo Y, Gerhart HD, Vaughan J, Kim JH, Glickman EL. Does acute normobaric hypoxia induce anapyrexia in adult humans? High Alt Med Biol. (2017) 18:185-90. doi: 10.1089/ham.2016.0139

61. Johnston CE, White MD, Wu M, Bristow GK, Giesbrecht GG. Eucapnic hypoxia lowers human cold thermoregulatory response thresholds and accelerates core cooling. J Appl Physiol. (1996) 80:422-9. doi: 10.1152/jappl.1996.80.2.422

62. Robinson KA, Haymes EM. Metabolic effects of exposure to hypoxia plus cold at rest and during exercise in humans. J Appl Physiol. (1990) 68:720-5. doi: 10.1152/jappl.1990.68.2.720

63. Keramidas ME, Kolegard R, Mekjavic IB, Eiken O. Acute effects of normobaric hypoxia on hand-temperature responses during and after local cold stress. High Alt Med Biol. (2014) 15:183-91. doi: 10.1089/ham.2013.1131

64. Savourey G, Guinet A, Besnard Y, Garcia N, Hanniquet AM, Bittel J. General and local cold responses in humans after 2 weeks at high altitude. Eur J Appl Physiol Occup Physiol. (1997) 75:28-33.

65. Launay JC, Besnard Y, Guinet-Lebreton A, Savourey G. Acclimation to intermittent hypobaric hypoxia modifies responses to cold at sea level. Aviat Space Environ Med. (2006) 77:1230-5. Available online at: https://www.asma. org/journal

66. O'Brien C, Castellani JW, Muza SR. Acute hypobaric hypoxia effects on finger temperature during and after local cold exposure. High Alt Med Biol. (2015) 16:244-50. doi: 10.1089/ham.2015.0024

67. Swoap SJ, Li C, Wess J, Parsons AD, Williams TD, Overton JM. Vagal tone dominates autonomic control of mouse heart rate at thermoneutrality. Am J Physiol Heart Circ Physiol. (2008) 294:H1581-8. doi: 10.1152/ajpheart.01000.2007

68. Bullard RW, Meyer FR. Relationship of the hypoxic heart rate response to ambient temperature. J Appl Physiol. (1966) 21:999-1003. doi: 10.1152/jappl.1966.21.3.999

69. Kovtun LT, Voevoda MI. Susceptibility to hypoxia and breathing control changes after short-term cold exposures. Int J Circumpolar Health (2013) 5:72. doi: 10.3402/ijch.v72i0.21574
70. Mortola JP, Matsuoka T, Saiki C, Naso L. Metabolism and ventilation in hypoxic rats: effect of body mass. Respir Physiol. (1994) 97:225-34. doi: 10.1016/0034-5687(94)90028-0

71. Haouzi P, Bell HJ, Notet V, Bihain B. Comparison of the metabolic and ventilatory response to hypoxia and $\mathrm{H} 2 \mathrm{~S}$ in unsedated mice and rats. Respir Physiol Neurobiol. (2009) 167:316-22. doi: 10.1016/j.resp.2009.06.006

72. Muratsubaki H, Enomoto K, Ichijoh Y, Yamamoto Y. Hypertriglyceridemia associated with decreased post-heparin plasma hepatic triglyceride lipase activity in hypoxic rats. Arch Physiol Biochem. (2003) 111:449-54. doi: $10.3109 / 13813450312331342319$

73. Siques P, Brito J, Naveas N, Pulido R, De la Cruz JJ, Mamani M, et al. Plasma and liver lipid profiles in rats exposed to chronic hypobaric hypoxia: changes in metabolic pathways. High Alt Med Biol. (2014) 15:388-95. doi: 10.1089/ham.2013.1134

74. Jun JC, Shin MK, Yao Q, Bevans-Fonti S, Poole J, Drager LF, et al. Acute hypoxia induces hypertriglyceridemia by decreasing plasma triglyceride clearance in mice. Am.J.Physiol Endocrinol.Metab. (2012) 303:E377-88. doi: 10.1152/ajpendo.00641.2011

75. Jun JC, Shin MK, Yao Q, Devera R, Fonti-Bevans S, Polotsky VY. Thermoneutrality modifies the impact of hypoxia on lipid metabolism. Am J Physiol Endocrinol Metab. (2013) 304:E424-35. doi: 10.1152/ajpendo.00515.2012

76. Baum D, Anthony CL Jr, Stowers C. Impairment of cold-stimulated lipolysis by acute hypoxia. Am J Dis Child. (1971) 121:115-9. doi: 10.1001/archpedi.1971.02100130069007

77. Jun JC, Shin MK, Devera R, Yao Q, Mesarwi O, Bevans-Fonti S, et al. Intermittent hypoxia-induced glucose intolerance is abolished by alphaadrenergic blockade or adrenal medullectomy. Am J Physiol Endocrinol Metab. (2014) 307:E1073-83. doi: 10.1152/ajpendo.00373.2014

78. Mahat B, Chasse E, Lindon C, Mauger JF, Imbeault P. No effect of acute normobaric hypoxia on plasma triglyceride levels in fasting healthy men. Appl Physiol Nutr Metab. (2018) 43:727-32. doi: 10.1139/apnm-2017-0505

79. Ferezou J, Richalet JP, Serougne C, Coste T, Wirquin E, Mathe D. Reduction of postprandial lipemia after acute exposure to high altitude hypoxia. Int J Sports Med. (1993) 14:78-85. doi: 10.1055/s-2007-1021150

80. Chopra S, Rathore A, Younas H, Pham LV, Gu C, Beselman A, et al. Obstructive sleep apnea dynamically increases nocturnal plasma free fatty acids, glucose, and cortisol during sleep. J Clin Endocrinol Metab. (2017) 102:3172-81. doi: 10.1210/jc.2017-00619

81. Mahat B, Chasse E, Mauger JF, Imbeault P. Effects of acute hypoxia on human adipose tissue lipoprotein lipase activity and lipolysis. J Transl Med. (2016) 14:212. doi: 10.1186/s12967-016-0965-y

82. Budinger GR, Duranteau J, Chandel NS, Schumacker PT. Hibernation during hypoxia in cardiomyocytes. Role of mitochondria as the $\mathrm{O} 2$ sensor. $\mathrm{J}$ Biol Chem. (1998) 273:3320-6. doi: 10.1074/jbc.273.6.3320

83. Cai Z, Manalo DJ, Wei G, Rodriguez ER, Fox-Talbot K, Lu H, et al. Hearts from rodents exposed to intermittent hypoxia or erythropoietin are protected against ischemia-reperfusion injury. Circulation (2003) 108:79-85. doi: 10.1161/01.CIR.0000078635.89229.8A

84. Jun JC, Rathore A, Younas H, Gilkes D, Polotsky VY. Hypoxiainducible factors and cancer. Curr Sleep Med Rep. (2017) 3:1-10. doi: 10.1007/s40675-017-0062-7

85. Samanta D, Semenza GL. Metabolic adaptation of cancer and immune cells mediated by hypoxia-inducible factors. Biochim Biophys Acta (2018) 1870:1522. doi: 10.1016/j.bbcan.2018.07.002

86. Mortola JP. How newborn mammals cope with hypoxia. Respir Physiol. (1999) 116:95-103. doi: 10.1016/S0034-5687(99)00038-9

Conflict of Interest Statement: The authors declare that the research was conducted in the absence of any commercial or financial relationships that could be construed as a potential conflict of interest.

Copyright (C) $2018 \mathrm{Gu}$ and Jun. This is an open-access article distributed under the terms of the Creative Commons Attribution License (CC BY). The use, distribution or reproduction in other forums is permitted, provided the original author(s) and the copyright owner(s) are credited and that the original publication in this journal is cited, in accordance with accepted academic practice. No use, distribution or reproduction is permitted which does not comply with these terms. 